Pak. j. sci. ind. res. Ser. A: phys. sci. 201558 (3) 130-135

\title{
Effect of Heat Treatment on Yield and Quality of Loofah (Luffa cylindrica Linn.) Seed Oil
}

\author{
Rahman Akinoso*a , Ademola Kabir Aremu ${ }^{\mathrm{b}}$ and Nnena Akosima \\ ${ }^{a}$ Department of Food Technology, University of Ibadan, Nigeria \\ ${ }^{b}$ Department of Agricultural and Environmental Engineering, University of Ibadan, Nigeria
}

(received May 30, 2014; revised November 7, 2014; accepted November 13, 2014)

\begin{abstract}
Effect of heat treatment on yield and some quality parameters of loofah seed (Luffa cylindrica Linn.) oil was the focus of this study. Central composite rotatable response surface methodology design for two variables was used for this investigation. Fatty acid composition of the un-treated oil was determined. The independent variables roasting temperature were $102,110,130,150,158{ }^{\circ} \mathrm{C}$ and duration $16,20,30$, 40, 44 min while oil yield, moisture content, free fatty acid, colour, refractive index and specific gravity of the oil were the dependent variables. All determinations were done using standard methods. Linoleic acid (50.66\%), oleic acid (27.66\%), palmitic acid (12.28\%) and stearic acid (6.44\%) were the major fatty acids. Mean oil yield, moisture, free fatty acid, colour, refractive index and specific gravity were $25.91 \pm 5.16 \%$, $0.035 \pm 0.003 \%, 5.3 \pm 2.47 \%, 15.23 \pm 1.83 \mathrm{mg} / 100 \mathrm{~g}, 1.47 \pm 0.002 \mathrm{ND}^{40}$ and $0.913 \pm 0.02$, respectively. All the parameters were significantly affected by heat treatment $(\mathrm{p}<0.05)$. Regression models were not fit to express the relation, thus optimisation using response surface approach was not adequate.
\end{abstract}

Keywords: Luffa cylindrica, heat treatment, seed oil, yield

\section{Introduction}

Oilseed crops are very important component of modern agriculture, for they provide easily available and highly nutritious human and animal food (Akinoso, 2006). The rate of vegetable oil consumption is increasing as compared with animal fat due to its health implication (Akinoso, 2006). Apart from being nutritious, edible vegetable oils often have industrial uses which include livestock feed, manufacture of adhesives, oleo chemicals, bio-fuel and medicinal resources. The largest sources of vegetable oil are annual plants which include soybean, corn, cotton seed, groundnut, sunflower seed, rapeseed, melon seed and sesame seed (O'Brien, 2008, Frank, 1988). Other sources are oil bearing perennial plants such as olive, coconut, shear, cashew, and seed include canola, citrus seed, cocoa, palm kernel, avocado and loofah seed. Luffa cylindrica Linn, commonly known as Loofah is an annual plant commonly found in the tropics including Nigeria and the seed contains about $30 \%$ oil (Bamgboye and Oniya, 2012). It is a member of the family Cucurbitaceae, a large plant family found mainly in the warmer parts of all continents. Fruits, leaves, flowers and seeds of Cucurbitaceae have considerable economic value. The seeds of the Cucurbitaceae family available in markets

*Author for correspondence; E-mail: akinoso2002@yahoo.com throughout West Africa are important source of oil used for food (Schipper, 2002). Domestic and industrial applications of $L$. cylindrica seed oil has been reported earlier by Gafar et al. (2012) Sangh et al. (2012) and Elemo et al. (2011).

Separation of oil involves three basic methods which are extraction method, mechanical oil expression and combination of the two methods. In extraction method, the extraction agent (solvent, aqueous, supercritical $\mathrm{CO}_{2}$ ) when brought in contact with the oilseeds, dissolves the oil present in the seed. The mixture is separated by evaporation to recover pure oil. The method is most popular in North America, it is highly efficient over $98 \%$ oil recovery and a single extractor can handle very large capacity up to 4000 tonnes per day (Akinoso et al., 2006). Pretreatments are conventional methods of preparing oilseeds for oil extraction. These include operations such as grinding, roasting, dehulling, flaking, cooking or steaming. It is usually carried out to fractionate oil intact bodies in order to enhance the release of oil during extraction (Kumar et al., 2009). Most oil seeds and nut are heat- treated by roasting to liquefy the oil in the plant cells and facilitate its release during extraction (Cammerer and Kroh, 2009).

Response surface methodology is a collection of statistical and mathematical techniques useful for developing, 
improving and optimising processes. It is important in designing, formulating, developing and analysing new scientific studies and products. It is also efficient in the improvement of existing studies and products (Montgomery, 2005). Response surface methodology is widely used in food science, industrial, biological and clinical sciences, social sciences and physical health education. Some reported applications of response surface approach in food processing include effects of natural additives on some quality parameters of un-refined peanut oil (Akinoso and Ekaette, 2012), extraction of oil from melon (Akinoso and Oni, 2012) and production of dried apple currant cubes (Diamante and Yamaguchi, 2012).

Consumption of fresh L. cylindrica fruit and use of fibre have been widely reported (Italo and Qswaldo, 2005; Bal et al., 2004; Onelli et al., 2001). The loofah seed which contains about $30 \%$ oil content is often discarded as waste and literature is sparse on extraction and quality of its seed oil. Therefore, effect of heat treatment on yield and quality of $L$. cylindrica seed oil using response surface methodology was the focus of this study.

\section{Materials and Methods}

Characterisation of the oil. Oil was extracted from untreated sample of loofah seed collected in Ibadan, Nigeria by Soxhlet extraction method using $n$-hexane as solvent. Sample of the extracted oil was fractionated by thin layer chromatography (TLC model QIG-38, Quark Enterprises Inc. Vineland, NJ) using hexane-ether-acetic acid (80:20:1) as developing agent. The spots were detected with $50 \%$ sulphuric acid and identified by comparison with standards. The relative percentage of each spot was measured on a scanning densitometer (Transidyne Model 2955, Transidyn General Corp. Ann. Arbor Michigan). Fatty acid composition of the oil was determined by reported method (Tahira et al., 2007). The fatty acids were converted to their respective methyl esters prior to analysis. The oil sample $(50 \mu \mathrm{L})$ was methylated in $4 \mathrm{~mL}$ $\mathrm{KOH}(1 \mathrm{M})$ for $1 \mathrm{~h}$ at room temperature. The resultant acid methyl esters (FAME) were extracted with high performance liquid chromatography (HPLC, model LC2010, Shimadzo Tokyo, Japan) grade hexane and analysed by gas chromatograph (model GC-2010, Shimadzu, Japan) immediately using a fused capillary column (WCOT fused silica $30 \mathrm{~m} \times 0.25 \mathrm{~mm}$ coating CPWAX $52 \mathrm{CBDF}=0.25 \mu \mathrm{M}, \mathrm{CP} 8713$ ), a flame ionisation detector (FID) and nitrogen gas as carrier $(3.5 \mathrm{~mL} / \mathrm{min})$. Gas chromatograph split ratio was $100 \%$. Injector and detector temperatures were $260{ }^{\circ} \mathrm{C}$ and column oven temperature was $222{ }^{\circ} \mathrm{C}$ for $7.5 \mathrm{~min}$. Fatty acid methyl ester peaks were identified by comparing their retention time with those of standards.

Experimental design. A central composite rotatable design of response surface methodology for two variables was employed. The independent variables were roasting temperature and duration while oil yield, moisture content, free fatty acid, colour, refractive index and specific gravity of the oil were the dependent variables. Factors considered in this study and their levels were based on information from literature and preliminary laboratory investigations (Akinoso and Oni, 2012; Gafar et al., 2012,). Nine experimental combinations were generated, and centre point was repeated four times (Table 1).

Determination of roasting temperature and duration. Roasting temperature was achieved by reported method (Akinoso, 2006). For each run, $50 \mathrm{~g}$ of ground sample were thinly spread in a petri dish and placed in preset temperature controlled oven at different temperatures and time combinations. A thermometer was used to verify the oven temperature. Stopwatch was used to monitor the time.

Determination of oil yield. Oil extraction was done using AOAC 920.39C method (AOAC, 2007). Whole roasted sample was $50 \mathrm{~g}$ packed in a Whatman's filter paper and inserted into the Soxhlet extractor. Petroleum ether was used as the extracting solvent. After six continuous hours of extraction, solvent was recovered by simple distillation and the residual oil was oven-dried at $65 \pm 2{ }^{\circ} \mathrm{C}$ for $1 \mathrm{~h}$. The sample was cooled in desiccator before being weighed. Drying, cooling and weighing processes were repeated until a constant dry weight was obtained. Oil yield in percentage was calculated using equation 1 .

Determination of moisture content. The moisture content of the sample was determined using ASABE (2010)

Oil yield $(\%)=\frac{\text { weight of extrected oil }}{\text { weight of seed }} \times 100$

standard for oilseeds. Three samples each weighing $15 \mathrm{~g}$ was placed in an oven set at $130^{\circ} \mathrm{C}$ for $6 \mathrm{~h}$. The samples were then cooled in a glass jar containing silica gel as desiccant. Ratio of difference in weight and initial material was recorded as moisture content.

Determination of free fatty acid content of the oil. Fatty acid analysis provides a rapid and accurate means of determining properties of fats and oil products. It is useful for product development, process control and marketing. Physical, chemical and nutritional characteristics 
of fats and oils are influenced by the kinds and proportion of the component fatty acids and their position on the glycerol radical (Weiss, 2000).

Free fatty acid was calculated using the AOCS method Ca5a - 40 (AOAC, 1997). Mixture of $1.0 \mathrm{~g}$ of oil, $25 \mathrm{~mL}$ of diethyl ether, $25 \mathrm{~mL}$ of alcohol and $1 \mathrm{~mL}$ of phenolphthalein solution was prepared. The mixture was titrated with aqueous $0.5 \mathrm{~N} \mathrm{NaOH}$, vigorously shook until a permanent faint pink colour appeared and persisted for 15 sec. The percentage of free fatty acid in the sample was calculated using below given equation 2 .

Free fatty acid $(\%)=\frac{\text { titration }(\mathrm{mL}) \times 0,141}{\text { weight of sample used }} \times 100$

Determination of oil colour. The colour of the oil was determined according to AOCS Cc 13c -50 (AOAC, 1997) standard methods with the aid of a spectrophotometer. The oil colour was measured by diluting $1 \mathrm{~mL}$ of oil sample with $9 \mathrm{~mL}$ of petroleum ether and read on spectronic $21 \mathrm{D}$ at $420 \mathrm{~nm}$ wavelength. The meter reading was multiplied by 10 to give the colour concentration in $\mathrm{mg} / 100 \mathrm{~g}$.

Determination of refractive index. This was determined using the Abe refractometer. The refractometer was first standardised to 1.3333 using distilled water at a temperature of $25^{\circ} \mathrm{C}$. This water was cleaned off with tissue paper and replaced with about $0.5 \mathrm{~g}$ of oil sample. The dark and light regions of the refractometer were adjusted to meet at an intercept of a crossbar before the readings were taken.

Determination of specific gravity. An empty pycnometer bottle was weighed, filled with water and reweighed. The oil was poured into the cleaned, dried bottle and then its weight was noted. Specific gravity was calculated using equation 3 .

$$
\text { Specific gravity }=\frac{\begin{array}{l}
\text { wt. of bottle and oil- } \\
\text { wt. of empty bottle }
\end{array}}{\begin{array}{l}
\text { wt. of bottle and water- } \\
\text { wt. of empty bottle }
\end{array}}
$$

Statistical analysis. The experimental procedures were replicated three times; mean values were recorded as obtained data. Data were analysed using Design Expert Version 6.0.10 (Stat Ease Minneapolis, USA) software package to generate regression equations and Analysis of Variance (ANOVA) which were determined at 5\% level of significance. Suitability of the models was determined by P-value, coefficients of determination $\left(\mathrm{R}^{2}\right)$, adjusted $\mathrm{R}^{2}$, predicted $\mathrm{R}^{2}$ and adequate precision.

\section{Results and Discussion}

Fatty acid composition. Fatty acid curve and composition of untreated L. cylindrica (Linn.) seed oil is presented in Table 2. Linoleic acid (50.66\%), oleic acid (27.66\%), palmitic acid (12.28\%) and stearic acid (6.47\%) accounts for $97.07 \%$ of the composition. Elemo et al. (2011) reported similar observation. Grape seed and safflower seed oils possess similar characteristics (Codex, 1999). Linoleic, the highest acid content is an essential nutrient in mammals.

Oil yield. Recorded oil yield ranged from 12.55 to $32.37 \%$ (Table 1). Roasting for $20 \mathrm{~min}$ at $150{ }^{\circ} \mathrm{C}$ gave least oil yield while highest oil yield was obtained when $L$. cylindrica seed was heated at $158.28{ }^{\circ} \mathrm{C}$ for $30 \mathrm{~min}$. Heating significantly affect $(\mathrm{P}<0.05)$ oil recovered from $L$. cylindrica seed (Table 1). All indexes used to verify fitness of the generated model (Table 3) showed poor fitness (Table 4). Seeds with oil content greater than $17 \%$ are classified as oil seed (Akinoso, 2006). Oil content of this seed (32.37\%) is higher than corn (18-20\%), soybean (18-20\%), cotton (18-20\%), olive (25-30\%), and at par with safflower (30$35 \%$ ) and sunflower (30-35\%) seeds which are all classified among largest sources of vegetable oils (O'Brien, 2008). It is commonly agreed by most reported works on oil recovery from seed/kernel/nut/fruit that heating of oil bearing material aids moisture loss, breakdowns oil cell walls, coagulates protein and reduces viscosity. All these attributes promote easy flow of oil (Akinoso, 2006). Akinoso and Raji (2011) reported possibility of case hardening of oil seeds during un-controlled heating which hindered oil flow. This explains significant influence of heat treatment on L. cylindrica seed oil yield. Non-fitness of the model suggested appropriateness of using mean value $(25.19 \pm 5.5 .16 \%)$ to present relationship between heating and oil yield than regression analysis.

Moisture content. The effect of heat treatment on moisture content of extracted L. cylindrica oil was significant $(\mathrm{P}<0.05)$ with overlapping subsets (Table 1). Moisture content varied between 0.029 and $0.045 \%$. Permissible moisture impurity in oil is $0.2 \%$ (Codex, 1999). Since temperature aid dehydration and moisture evaporation, and most of the samples were heated above $100{ }^{\circ} \mathrm{C}$, noticeable influence of heating on oil samples was expected. Akinoso (2006) reported similar observation for palm kernel. Moisture is one of the non-fatty impurities present in oil. It contaminates the oil during processing. Sleeter (1983) reported that continued presence of moisture in oil induces hydrolysis with a resultant free fatty acid and offflavours. 
Table 1. Design matrix and responses

\begin{tabular}{llllllll}
\hline \hline $\begin{array}{l}\text { Roasting } \\
\text { temperature } \\
\left({ }^{\circ} \mathrm{C}\right)\end{array}$ & $\begin{array}{l}\text { Roasting } \\
\text { duration } \\
(\mathrm{min})\end{array}$ & $\begin{array}{l}\text { Oil } \\
\text { yield } \\
(\%)\end{array}$ & $\begin{array}{l}\text { Moisture } \\
\text { content } \\
(\%)\end{array}$ & $\begin{array}{l}\text { Free } \\
\text { fatty acid } \\
(\%)\end{array}$ & $\begin{array}{l}\text { Colour } \\
(\mathrm{mg} / 100 \mathrm{~g})\end{array}$ & $\begin{array}{l}\text { Refractive } \\
\text { index } \\
\left(\mathrm{ND}^{40}\right)\end{array}$ & $\begin{array}{l}\text { Specific } \\
\text { gravity } \\
\left(\mathrm{x}{ }^{\circ} \mathrm{C} / \text { water }\right. \\
\left.\text { at } 30^{\circ} \mathrm{C}\right)\end{array}$ \\
\hline 110 & 20.00 & $21.96^{\mathrm{c}}$ & $0.029^{\mathrm{d}}$ & $3.09^{\mathrm{b}}$ & $16.01^{\mathrm{f}}$ & $1.47^{\mathrm{ab}}$ & $0.867^{\mathrm{a}}$ \\
150 & 20.00 & $12.55^{\mathrm{a}}$ & $0.036^{\mathrm{cd}}$ & $12.06^{\mathrm{h}}$ & $11.46^{\mathrm{b}}$ & $1.47^{\mathrm{ab}}$ & $0.906^{\mathrm{c}}$ \\
110 & 40.00 & $19.6^{\mathrm{b}}$ & $0.038^{\mathrm{e}}$ & $3.36^{\mathrm{c}}$ & $16.72^{\mathrm{g}}$ & $1.47^{\mathrm{b}}$ & $0.923^{\mathrm{e}}$ \\
150 & 40.00 & $30.15^{\mathrm{g}}$ & $0.037^{\mathrm{de}}$ & $4.77^{\mathrm{e}}$ & $12.88^{\mathrm{c}}$ & $1.47^{\mathrm{a}}$ & $0.926^{\mathrm{f}}$ \\
130 & 44.00 & $29.02^{\mathrm{e}}$ & $0.045^{\mathrm{g}}$ & $10.79^{\mathrm{g}}$ & $11.22^{\mathrm{a}}$ & $1.47^{\mathrm{bc}}$ & $0.872^{\mathrm{b}}$ \\
130 & 16.00 & $32.34^{\mathrm{h}}$ & $0.037^{\mathrm{de}}$ & $3.37^{\mathrm{c}}$ & $17.86^{\mathrm{i}}$ & $1.47^{\mathrm{b}}$ & $0.912^{\mathrm{d}}$ \\
158 & 30.00 & $32.37^{\mathrm{i}}$ & $0.035^{\mathrm{c}}$ & $6.03^{\mathrm{f}}$ & $13.13^{\mathrm{d}}$ & $1.48^{\mathrm{d}}$ & $0.912^{\mathrm{d}}$ \\
102 & 30.00 & $29.41^{\mathrm{f}}$ & $0.041^{\mathrm{f}}$ & $2.95^{\mathrm{a}}$ & $13.88^{\mathrm{e}}$ & $1.47^{\mathrm{b}}$ & $0.925^{\mathrm{g}}$ \\
130 & 30.00 & $25.8^{\mathrm{d}}$ & $0.032^{\mathrm{b}}$ & $4.49^{\mathrm{d}}$ & $16.96^{\mathrm{h}}$ & $1.48^{\text {cd }}$ & $0.925^{\mathrm{g}}$ \\
130 & 30.00 & $25.87^{\mathrm{d}}$ & $0.031^{\mathrm{b}}$ & $4.48^{\mathrm{d}}$ & $16.9^{\mathrm{h}}$ & $1.47^{\text {cd }}$ & $0.925^{\mathrm{g}}$ \\
130 & 30.00 & $25.85^{\mathrm{d}}$ & $0.033^{\mathrm{b}}$ & $4.47^{\mathrm{d}}$ & $16.98^{\mathrm{h}}$ & $1.47^{\mathrm{cd}}$ & $0.926^{\mathrm{g}}$ \\
130 & 30.00 & $25.90^{\mathrm{d}}$ & $0.030^{\mathrm{b}}$ & $4.49^{\mathrm{d}}$ & $16.97^{\mathrm{h}}$ & $1.48^{\mathrm{cd}}$ & $0.926^{\mathrm{g}}$ \\
130 & 30.00 & $25.88^{\mathrm{d}}$ & $0.033^{\mathrm{b}}$ & $4.50^{\mathrm{d}}$ & $16.95^{\mathrm{h}}$ & $1.48^{\text {cd }}$ & $0.926^{\mathrm{g}}$ \\
\hline \hline
\end{tabular}

Values with different superscript in the same column are significantly different at $5 \%$ level of significance.

Free fatty acid. Free fatty acid of the oil samples varied between 2.95 and $12.06 \%$ (Table 1). Recorded mean was $5.3 \pm 2.47 \%$. Free fatty acid is one of the major quality parameters of edible oil. Regression model (Table 3) was not also fit to explain the relationship (Table 4). None of the samples gave acceptable free fatty as recommended by Codex (1999). Recommended standard for refined and un-refined edible oil were 0.3 and $2.0 \%$, respectively. Heat treatment significantly affected free fatty acid contents of L. cylindrica oil (Table 1). Free fatty acid is formed due to the hydrolysis of triglyceride and is responsible for off flavour development during storage. High temperature, moisture and presence of active lipase are responsible for the formation of free fatty acid in fat and oil (Kumar et al., 2009). Extensive heat treatment can result in production of non-volatile oxidised derivatives and oxidation rate double for every $15^{\circ} \mathrm{C}$ increase in temperature (Hui, 1996). Therefore, obtained results may be adduced to those reasons.

Colour. Heat treatment significantly influence colour intensity of the oil samples (Table 2). Recorded mean colour was $15.23 \pm 1.83 \mathrm{mg} / 100 \mathrm{~g}$ (Table 4). Belbin (1993) reported that appearance properties have only aesthetic value with little influence on performance; however, abnormal appearance characteristics can indicate problems, such as poor handling, storage or processing techniques. Mohagir et al. (2009), reported colour formation by both non-enzymatic browning reaction and phospholipids degradation during heating. Akinoso et al. (2006) also traced increase in absorbance of thermally treated oils to
Table 2. Fatty acid composition of loofah seed oil

\begin{tabular}{lll}
\hline \hline Fatty acid & Code & \% composition \\
\hline Palmitic acid & C16:0 & 12.28 \\
Palmitic oleic acid & C16:1 & 0.08 \\
Stearic acid & C18:0 & 6.47 \\
Oleic acid & C18:1 & 27.66 \\
Linoleic acid & C18:2 & 50.66 \\
Linolenic acid & C18:3 & 0.75 \\
Arachidic acid & C20:0 & 2.03 \\
Behenic acid & C22:0 & 0.07 \\
\hline \hline
\end{tabular}

the formation of conjugated dienes and trienes which transformed into polymer compounds with increase in heat application.

Refractive index. The refractive index of the oil samples ranged between 1.47 and $1.48 \mathrm{~N}_{\mathrm{D}}{ }^{40}$ (Table 1), with mean of $1.47 \pm 0.002 \mathrm{~N}_{\mathrm{D}}{ }^{40}$. Heat significantly influenced the results (Table 1). This property is in same range for reported oil seeds like groundnut $\left(1.46-1.465 \mathrm{~N}_{\mathrm{D}}{ }^{40}\right)$, grape seed (1.467-1.477 $\left.\mathrm{N}_{\mathrm{D}}{ }^{40}\right)$, mustard seed (1.461-1.469 $\left.\mathrm{N}_{\mathrm{D}}{ }^{40}\right)$, sunflower seed (1.467-1.471 $\mathrm{N}_{\mathrm{D}}{ }^{40}$ ), soybean (1.466$\left.1.47 \mathrm{~N}_{\mathrm{D}}{ }^{40}\right)$ and sesame seed oils $\left(1.465-1.469 \mathrm{~N}_{\mathrm{D}}^{40}\right)$ (Codex, 1999). Refractive index of oil can be used to detect rancidity in edible oil. Arya et al. (1969) reported similar observations for effect of heat on refractive index of some edible oils.

Specific gravity. The highest and lowest specific gravity of the samples was 0.867 and 0.926 , respectively, (Table 1). Influence of the specific gravity on heat treatment was 
Table 3. Generated regression models

\begin{tabular}{lllllll}
\hline \hline Parameters & \multicolumn{5}{c}{ Coefficients } \\
\cline { 2 - 7 } & $\begin{array}{l}\text { Oil } \\
\text { yield } \\
(\%)\end{array}$ & $\begin{array}{l}\text { Moisture } \\
(\%)\end{array}$ & $\begin{array}{l}\text { Free } \\
\text { fatty acid } \\
(\%)\end{array}$ & $\begin{array}{l}\text { Colour } \\
\mathrm{mg} / 100 \mathrm{~g}\end{array}$ & $\begin{array}{l}\text { Refractive } \\
\text { index } \\
\left(\mathrm{N}_{\mathrm{D}}^{40}\right)\end{array}$ & $\begin{array}{l}\text { Specific } \\
\text { gravity }\end{array}$ \\
\hline Intercept & +114.79 & +0.10 & -44.84 & -49.66 & +1.38 & +0.96 \\
Temperature $\left({ }^{\circ} \mathrm{C}\right)$ & -0.71 & $-9.99 \mathrm{E}-004$ & +0.38 & +0.99 & $+9.69 \mathrm{E}-004$ & $-9.13 \mathrm{E}-003$ \\
Duration $(\mathrm{min})$ & -3.11 & $-5.18 \mathrm{E}-004$ & +1.27 & +0.49 & $+2.11 \mathrm{E}-003$ & +0.04 \\
Temperature $^{2}$ & - & $+4.94 \mathrm{E}-006$ & - & $-4.15 \mathrm{E}-003$ & $-2.91 \mathrm{E}-006$ & $+4.4 \mathrm{E}-005$ \\
Duration $^{2}$ & - & $+3.48 \mathrm{E}-005$ & - & -0.01 & $-2.16 \mathrm{E}-005$ & $-5.14 \mathrm{E}-004$ \\
Temp* Duration $^{2}$ & +0.02 & $-1.00 \mathrm{E}-005$ & $-9.45 \mathrm{E}-003$ & $+8.87 \mathrm{E}-004$ & $-6.25 \mathrm{E}-006$ & $-8.25 \mathrm{E}-005$ \\
\hline \hline
\end{tabular}

Table 4. Summary of regression analysis of the models

\begin{tabular}{lllllll}
\hline \hline Parameter & Mean & P-value & $\mathrm{R}^{2}$ & $\begin{array}{l}\text { Adjusted } \\
\mathrm{R}^{2}\end{array}$ & $\begin{array}{l}\text { Predicted } \\
\mathrm{R}^{2}\end{array}$ & $\begin{array}{l}\text { Adequate } \\
\text { precision }\end{array}$ \\
\hline Oil yield (\%) & $25.91 \pm 5.16$ & 2891 & 0.3276 & 0.1034 & -1.6132 & 4.405 \\
Moisture content (\%) & $0.035 \pm 0.00$ & .0755 & 0.7022 & 0.4994 & -0.9657 & 4.859 \\
Free fatty acid (\%) & $5.30 \pm 2.47$ & .1410 & 0.4388 & 0.2517 & -0.9824 & 5.447 \\
Colour (mg/100g) & $15.23 \pm 1.83$ & .1263 & 0.6464 & 0.3938 & -1.5144 & 3.992 \\
Refractive index $\left(\mathrm{N}_{\mathrm{D}}{ }^{40}\right.$ ) & $1.47 \pm 0.002$ & .4240 & 0.4472 & 0.0524 & -1.7109 & 2.642 \\
Specific gravity & $0.96 \pm 0.044$ & .1360 & 0.6373 & 0.3782 & -1.5790 & 4.824 \\
\hline \hline
\end{tabular}

significant (Table 1). Regression equation (Table 3 ) was not fit to describe the relationship between heat treatment of $L$. cylindrica seed and specific gravity due to negative prediction $\mathrm{R}^{2}$ (Table 4). It is a common knowledge that oil specific gravity, like other fluids, is temperature dependent. Specific gravity of oil is useful in design of handling equipment such as pump and pipe. In addition, specific gravity is directly related to relative density and is important in determining the quality of oil and efficiency of the extraction procedures. Due to negative prediction $\mathrm{R}^{2}$, the mean value $(0.913 \pm 0.02)$ is more appropriate to represent the result, and fall within the range (0.891-0.925) reported for vegetable oils by Codex (1999).

\section{Conclusion}

Major fatty acids in (L. cylindrica Linn.) seed oil were linoleic, oleic, palmitic and stearic acids. These account for $97.07 \%$ of detectable fatty acids in the oil. Whole loofah seed contains about $32 \%$ oil which has domestic and industrial potentials. Heating of seed significantly influenced oil quantity and quality (moisture impurity, free fatty acid, colour, refractive index and specific gravity). Regression models were not fit to express the relation, thus optimisation using response surface approach was not adequate. Study on anti-nutritional factors in the oil and development of de-hulling machine is recommended.

\section{References}

Akinoso, R., Ekaette, I.U. 2012. Natural additives effects on some quality parameters of un-refined peanut oil. African Journal of Food, Agriculture Nutrition and Development, 12: 6715- 6736.

Akinoso, R., Oni, P.O. 2012. Optimization of solvent extracted melon seed oil using response surface methodology. European Journal of Lipid Science Technology, 114: 607- 611.

Akinoso, R., Raji, A.O. 2011. Optimization of oil extraction from locust bean using response surface methodology. European Journal of Lipid Science and Technology, 113: 245- 252.

Akinoso, R., Igbeka, J.C., Olayanju, T.M.A. 2006. Predictive models for palm kernel (Elaeis guneensis) and sesame (Sesamum indicum) oil colour. Journal of Applied Science, Engineering and Technology, 6: 34-38.

Akinoso, R. 2006. Effect of Moisture Content, Roasting Duration and Temperature on Yield and Quality of Palm Kemel (Elaeis guinessis) and Sesame (Sesamum indicum) Oils. Ph.D. Thesis, University of Ibadan, Nigeria.

AOAC, 2007. Official Methods of Analysis, $18^{\text {th }}$ edition, Association of Official Analytical Chemists, Gaithersburg, MD, USA. 
AOCS, 1997. Official Methods and Recommended Practices of the American Oil Chemists'Society, American Oil Chemists' Society, Champaign, USA. Arya, S.S., Ramanujam, S., Vijayaraghavan, P.K. 1969. Refractive index as an objective method for evaluation of rancidity in edible oils and fats. Journal of the American Oil Chemists' Society, 46: 28-30.

ASAE/ASABE, 2010. ASAE/ASAE S410.2. Moisture Measurement-Peanut, pp.679-680, American Society of Agricultural and Biological Engineers, St. Joseph, Michigan, USA.

Bal, K.E., Bal, Y., Lallam, A. 2004. Gross morphology and absorption capacity of cell-fibers from the fibrous vascular system of loofah (Luffa cylindrica). Textile Research Journal, 74: 241-247.

Bamgboye, I.A., Oniya, O.O. 2012. Fuel properties of loofah (Luffa cylindrica L.) bio-fuel blended with diesel. African Journal for Environment Science and Technology, 6: 346-352.

Belbin, A.A. 1993. Colour in oils. International News on Fats, Oils and Related Materials INFORM, 4: 648-654.

Cammerer, B., Kroh, L.W. 2009. Shelf life of linseeds and peanuts in relation to roasting. Food Science and Technology, 9: 545-549.

Codex. 1999. Codex Standard for Fats and Oil from Vegetable Sources (CODEX-STAN 210-1999). FAO/WHO Food Standard Programme ALINORM.

Diamante, L.M., Yamaguchi, Y. 2012. Response surface methodology for optimization of hot air drying of black current concentrate infused apple cubes. International Food Research Journal, 19: 353-362.

Elemo, G.N., Elemo, B.O., Erukainure, O.L. 2011. Characterization of sponge gourd (Luffa aegyptiaca Mill.) seed oil. Journal of Tropical Agriculture, 4: 128-130.

Frank, T.O. 1988. Vegetable Oils, Bailey's Industrial Oil and Fat Product, pp. 19-44, John Wiley and Sons Inc., New York, USA.

Gafar, M.K., Itodo, A.U., Warra, A.A., Wyasu, G., Usman, J. 2012. Physicochemical, cold saponification and GC-MS analysis of sponge gourd (Luffa cylindrica Linn.) seed oil. International Journal on Modern
Chemistry, 3: 98-107.

Hui, Y.H. 1996. Edible Oil and Fat Products Processing Technology. In: Bailey's Industrial Oil and Fat Products, vol. 4, pp. 105-137, John Wiley and Sons Inc. New York, USA.

Kumar, S., Debnath, S., Hebbar, U.H. 2009. Pulsed infrared roasting of groundnuts and its quality. International Journal of Food Engineering, 5: 1-15.

Italo, M.O., Alves, O.L. 2005. Morpho synthesis: high fidelity inorganic replica of the fibrous network of loofah sponge (Luffa cylindrica). Anais da Academia Brasileira de Ciências, 77: 25-31.

Mohagir, A.M., Kamga, R., Kapseu, C., Abi, C.F. 2009. Optimization of some pre-treatments involved in the press extraction of shea (Vitellaria paradoxa Gaertner F.) Butter. Asian Journal of Applied Science, 2: 372-384.

Montgomery, D.C. 2005. Design and Analysis of Experiments: Response Surface Method and Designs, $6^{\text {th }}$ edition, pp. 521-523, John Wiley and Sons, Inc. New Jersey, USA.

O'Brien, R.D. 2008. Fats and Oils Formulating and Processing for Application, pp. 183-223, Technical Publishing Company Inc., Lancaster, USA.

Onelli, E., Patrignani, G., Carraro, L. 2001. Spatial arrangement of the fibres in developing and mature endocarp of Luffa cylindrica. Plant Biosystems, 135: 39-44.

Sangh, P., Amit, K., Neeraj, K.S., Jha, K.K. 2012. Luffa cylindrica. An important medicinal plant. Scholars Research Library, 2: 127-134.

Schippers, R.R. 2002. African Indigenous Vegetables. An Over View of the Cultivated Species, revised version on CD ROM, Natural Resources International Limited, UK.

Sleeter, R.T. 1983. Instrument analytical methods for edible oil processing: Present and future. Journal of the American Oil Chemists' Society, 60: 343-349.

Tahira, R., Rehman, A., Butt, M.A. 2007. Characterization of rice bran oil. Journal of Agricultural Research, 45: 225-230.

Weiss, E.A. 2000. Oil Seed Crop, pp. 131-164, $2^{\text {nd }}$ edition Blackwell Sciences, London, UK. 